
D.D. Zerbino ${ }^{1}$, D.I. Besh ${ }^{2}$, M.Yu. Sokolov ${ }^{4}$, O.M. Besh ${ }^{3}$

\section{CORRELATIONS BETWEEN MORPHOLOGICAL FEATURES OF INTRACORONARY THROMBI AND LEFT VENTRICULAR STRUCTURE AND FUNCTION IN PATIENTS WITH ST-SEGMENT ELEVATION MYOCARDIAL INFARCTION}

Danylo Halytsky Lviv National Medical University

Museum of Human Diseases ${ }^{1}$

Department of Family medicine ${ }^{2}$

Department of Internal medicine $N 2^{3}$

Pekarska str., 69, Lviv, 79010, Ukraine

National Scientific Center «M.D. Strazhesko Institute of Cardiology» of NAMS of Ukraine 4

Narodnoho Opolchennia str, 5, Kyiv, 03151, Ukraine

Львівський національний медичний університет імені Данила Галицького

Музей хвороб людини ${ }^{l}$

(дир. - д. мед. н., проф., акад. НАМН Украӥни Д.Д. Зербіно)

кафедра сімейної медииини ФПДО ${ }^{2}$

(зав. - д. мед. н., проф. Ю.Г. Кияк)

кафедра внутрішньої медицини № $2^{3}$

(зав. - д. мед. н., проф. О.М. Радченко)

вул. Пекарська, 69, Львів, 79010, Украӥна

Національний науковий ичентр "Інститут кардіологї імені М.Д. Стражеско» ${ }^{4}$

(дир. - д. мед. н., проф., акад. НАМН Украӥни В.М. Коваленко)

вул. Народного Ополчення, 5, 03151, Київ, Украӥна

e-mail:beshd@hotmail.com

Цитування: Медичні перспективи. 2020. Т. 25, № 3. С. 62-70

Cited: Medicni perspektivi. 2020;25(3):61-70

Key words: acute ST-elevation myocardial infarction, morphological features of thrombi, manual thromboaspiration, prognosis, percutaneous coronary intervention

Ключові слова: гострий інфаркт міокарда з елевачією сегмента ST, морфологічні характеристики тромбів, мануальна тромбоаспірація, прогноз, черезшкірне коронарне втручання

Ключевые слова: острый инфаркт миокарда с элевацией сегмента $S T$, морфологические характеристики тромбов, мануальная тромбоаспирация, прогноз, чрескожное коронарное вмешательство

\begin{abstract}
Correlations between morphological features of intracoronary thrombi and left ventricular structure and function in patients with ST-segment elevation myocardial infarction. Zerbino D.D., Besh D.I., Sokolov M.Yu., Besh O.M. The majority of cases of acute ST-elevation myocardial infarction (STEMI) are caused by the rupture of an atherosclerotic plaque and subsequent thrombus formation. The study of clot structure may be important for the prediction of further course of the disease. The study included 100 patients with STEMI who underwent primary percutaneous coronary intervention (PCI) with manual thromboaspiration within the first 12 hours after the onset of symptoms. Sufficient aspiration material for histological examination was obtained in 97 patients. These intracoronary thrombi were investigated macroscopically and microscopically. Subsequently, correlations between morphological structure of thrombi and structural and functional features of the myocardium after

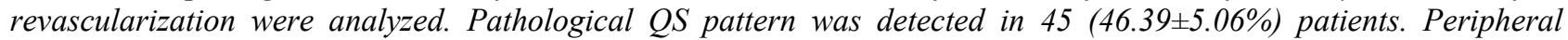
infiltration of intracoronary thrombus with neutrophils was the only morphological feature associated with the presence of $Q S(r=-0.36 ; p<0.001)$. The mean left ventricular ejection fraction (LVEF) measured during echocardiography was 48.34 $9.39 \%$. Positive and significant correlation was found between LVEF and peripheral infiltration of intracoronary thrombus with neutrophils $(r=0.37 ; p<0.001)$, while negative correlation was found between LVEF and presence of microchannels within the clot $(r=-0.27 ; p<0.01)$. The mean total segmental left ventricular contractility index at the time of hospital discharge was 1.38 [1.25; 1.63]. This index negatively correlated with neutrophil infiltration $(r=-0.37 ; p<0.001)$, and positively - with the presence of microchannels in the obtained clot samples $(r=0.26 ; p=0.01)$. Signs of left ventricular aneurysm formation before discharge from the hospital were
\end{abstract}


found in 15 (15.46 $\pm 3.67 \%)$ patients. A significant negative correlation was found between this parameter and the presence of peripheral neutrophil infiltration of intracoronary thrombi $(r=-0.32 ; p<0.01)$. The presence of peripheral infiltration of intracoronary thrombi with neutrophil leukocytes was associated with better left ventricular systolic function and less likely hood of development of left ventricular aneurysm or electrocardiographic QS pattern. The formation of microchannels within the clot was associated with poorer recovery of systolic cardiac function.

Реферат. Оценка связей между морфологическими особенностями интракоронарных тромбов и структурно-функциональным состоянием левого желудочка у пациентов с инфарктом миокарда с элевацией сегмента ST. Зербино Д.Д., Беш Д.И., Соколов М.Ю., Беш О.М. Чаще всего развитие острого инфаркта миокарда с элеваџией сегмента ST (STEMI) обусловлено разрывом атеросклеротической бляшки с последующим формированием тромба. Изучение его строения играет существенную роль в прогнозировании дальнейшего течения заболевания. В исследование вошло 100 пациентов с STEMI, которым в первые 12 часов от начала развития симптомов провели первичное чрескожное коронарное вмешательство с применением мануальной тромбоаспирации. Достаточный для гистологического исследования аспирационньй материал был получен у 97 пациентов. Полученные интракоронарные тромбы анализировали макроскопически и микроскопически и в дальнейшем изучали корреляционные связи морфологической структуры тромбов со структурно-функциональными особенностями миокарда после реваскуляризачии. Патологический зубеи $Q S$

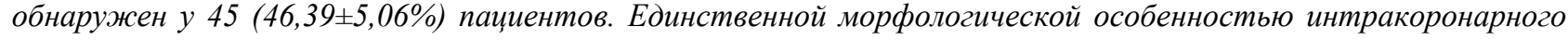
тромба, у которой была найдена взаимосвязь с данным показателем, было наличие периферической инфильтрации нейтрофильными лейкоцитами $(r=-0,36 ; p<0,001)$. Фракция выброса левого желудочка при

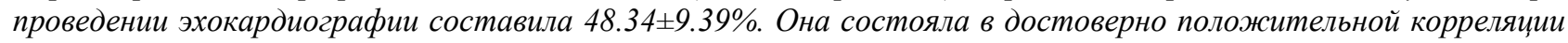
с наличием инфильтрации нейтрофилов периферических участков тромба $(r=0,37 ; p<0,001)$ и отрицательной - с формированием микроканалов в тромбах $(r=-0,26789 ; p<0,01)$. Суммарная сократимость миокарда левого желудочка на момент выписки из стационара составила 1.38 [1.25; 1.63]. Статистически достоверно отрицательная корреляционная связь была обнаружена с инфильтрацичей нейтрофилами $(r=-0,37 ; p<0,001)$, a значимо положительная - с наличием микроканалов в полученных образцах тромбов $(r=0,26 ; p=0,01)$. Признаки формирования аневризмы левого желудочка перед выпиской из стаџионара обнаружили у 15 (15,46士3,67\%) пациентов. Была выявлена достоверно отрицательная корреляция между данным показателем и наличием периферической инфильтрации нейтрофильными лейкоцитами $(r=-0,32 ; p<0,01)$. Наличие периферической инфильтрации нейтрофильнылм лейкоцитами интракоронарных тромбов связано с лучшими показателями систолической функции левого желудочка, меньшей вероятностью формирования аневризмьл и зубияа QS на ЭКГ. Формирование микроканалов в тромбах связано с худиим восстановлением систолической функции сердия.

Acute ST-segment elevation myocardial infarction (STEMI) is an important medical and social problem. According to the European Society of Cardiology, on our continent its prevalence in different countries ranges from 43 to 144 per 100,000 of population [13]. According to statistics, in Ukraine in 2016 the frequency of STEMI was 113.6 patients per 100,000 population, and tendency to its decrease is not observed recently [1].

Primary percutaneous coronary interventions are now an integral and key element in the treatment of patients in STEMI. Their use has led to a significant reduction in mortality and disability in the above pathology [13]. This situation is confirmed by the data of the Ukrainian Register of Percutaneous Coronary Interventions. According to its results, in the areas with the best coverage of patients with reperfusion care with STEMI, mortality decreased from $14.2 \%$ in 2015 to $11.6 \%$ in 2017 . Thus, in 2017 there were saved 420 lives more than in 2015, which madeit possible to achieve a general reduction in mortality from this pathology in our country from $13.2 \%$ in 2016 to $12.5 \%$ in 2017 . However, the situation is still quite serious [3].
Most often, the development of STEMI is due to the rupture of atherosclerotic plaque in the coronary artery with the subsequent formation of a thrombus on its surface [7]. It is believed that the morphological structure of the thrombus can significantly explain the pathogenesis of the disease. The only method that makes it possible to obtain a thrombus from the coronary artery when alive is to perform manual thromboaspiration within the primary percutaneous coronary intervention [9]. But data on the need for routine involvement of manual thromboaspiration in this intervention are contradictory [13].

To date, there are a number of studies that have examined the likely impact of different characteristics of intracoronary blood clots on the prognosis of patients with STEMI. Most often the prognostic significance of their age (time from the beginning of formation to thromboaspiration) was determined. The results of this type of research are quite ambiguous and do not provide a clear answer to questions about the role of this indicator. Another minus of these studies is that they determine the age of the thrombus by indirect signs, which can be 
influenced by a number of factors other than the duration of the disease $[9,10]$.

In recent years, much attention has been paid to the influence of neutrophilic leukocytes as triggers of the thrombotic process. It is proved that they are able to produce neutrophilic traps, which can stimulate thrombus formation at the site of rupture of the atherosclerotic plaque by providing a framework for fibrin fiber deposition [6].

There are isolated data about the influence of other characteristics of intracoronary thrombi obtained by manual thromboaspiration on various indicators of disease prognosis [12]. However, today there is a lack of data to clearly understand which of the morphological features of thrombi can be used to assess the further course of STEMI. In particular, there are very little data on their effect on the structural and functional state of the left ventricle.

The aim of our study was to examine the relationship between the morphological features of intracoronary thrombi and the structural and functional state of the left ventricle 2-3 weeks after stenting the infarct-dependent coronary artery performed within the "therapeutic window" STEMI.

\section{MATERIALS AND METHODS OF RESEARCH}

The research was carried out on the basis of three medical institutions: the National Research Center "Institute of Cardiology named after MD Strazhesko", Kyiv, Municipal Non-Profit Enterprise "Clinical Ambulance Hospital", Lviv, and Municipal Non-Profit Enterprise of the Lviv Regional Council "Lviv Regional Clinical Medical and Diagnostic Cardiology Center". The study included 100 patients ( $22 \%$ women and $78 \%$ men) aged $57.81 \pm 10.26$ years with STEMI, who in the first 12 (average 7.00 [4.75; $10.00]$ ) hours from the onset of symptoms underwent primary percutaneous coronary intervention using manual thromboaspiration. The decision to involve the latter in the treatment process was made by the doctor who performed the procedure. Each patient on baseline coronary angiography showed massive thrombosis or occlusion of the infarctdependent coronary artery. Sufficient aspiration material for histological examination was obtained in 97 patients who were included in further observation. All of them gave informed consent to participate in the pre-investigation. The obtained intracoronary thrombi were analyzed macroscopically and divided into three groups: white, red and mixed. Subsequently, they were fixed in a neutral formalin solution, then filled with resin and stained by the standard method of hematoxylineosin, as well as by the method of orange-red-blue (Zerbino-Lukasevich method). The latter allows you to estimate the age of fibrin by color. If it turns red or pink, then less than 24 hours passed since the beginning of the formation. Blue or purple fibrin occurs more than a day before its fixation. The thrombus was considered old when the proportion of such fibrin was more than $30 \%$.

To analyze the relationship between the morphological characteristics of the obtained intracoronary thrombi and the prognosis of patients, the obtained thrombi according to certain characteristics were divided into the following groups:

- by age of the thrombus: old or fresh (according to the color of fibrin);

- by the structure of the thrombus (the presence of a layered structure or its absence);

- by the presence of microchannels;

- by the presence of peripheral infiltration with neutrophilic leukocytes (with or without neutrophilic infiltration on the periphery of the thrombus) (Fig.).

All patients in the period from 14 to 21 days after hospitalization underwent echocardiographic and ECG examination. The following indicators were studied: development of pathological QS wave in leads with ST segment elevation, ejection fraction, contractility index, dilatation and formation of left ventricular aneurysm ("frozen" ST segment elevation on ECG, dyskinesia and wall thinning in STEMI site). The total contractility of the left ventricular myocardium was assessed by 16 segments using the following scale: normal contractility - 1 point, hypokinesia - 2 points, akinesia 3 points, dyskinesia -4 points. The index of myocardial contractility (wall motion score) was calculated by the formula: total myocardial contractility of the left ventricle/ 16 [4].

LibreOffice Calc v.5.2.2.2 spreadsheets were used to form the database and calculate the obtained results. Statistical analysis of the results was performed on a personal computer using the program R. Calculations were performed in the program RStudio (RStudio, Inc.) license (Affero General Public License v3). The obtained results were presented in the form of mean values and their standard deviations $(\mathrm{M} \pm \mathrm{SD})$ in the case of Gaussian distribution and median, 25th and 75th percentiles (Me $[25 \% ; 75 \%]$ ) in the case of non-Gaussian distribution. Correlation analysis was performed by the Spearman method [2].

The analysis of baseline characteristics is presented in Table 1. Among 97 patients in whom we managed to obtain sufficient thrombotic material for analysis, $82.47 \%$ were men. The analysis of risk factors made it possible to obtain indicators of the 
frequency of concomitant pathology in patients who participated in the survey. Diabetes mellitus was found in $21.65 \%$ of patients, arterial hypertension in $57.73 \%$, obesity - in $41.24 \%$, chronic kidney disease - in $20.62 \%$. Dyslipidemia was recorded in $32.99 \%$ of patients, $56.70 \%$ of patients smoked. A detailed study of the professional history of patients revealed that $51.55 \%$ of them had contact with xenobiotics in the workplace. Cardiogenic shock at hospitalization was diagnosed in $11.34 \%$ of patients.
Coronary angiography showed that in $42.27 \%$ of patients the anterior interventricular branch of the left coronary artery was infarct-dependent. Atherosclerotic lesions of more than one coronary artery were found in $40.21 \%$ of patients. Assessment of blood flow and the state of the microcirculatory tract showed that the complete absence of blood flow (TIMI 0) was observed in $82.47 \%$, and the absence of signs of perfusion of the microcirculatory tract (MBG 0) was registered in $88.66 \%$ of patients.

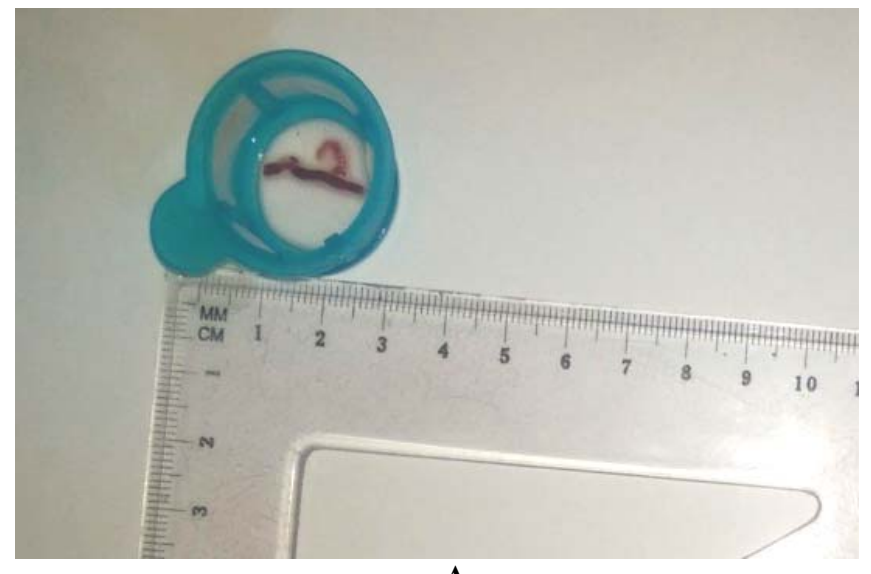

A

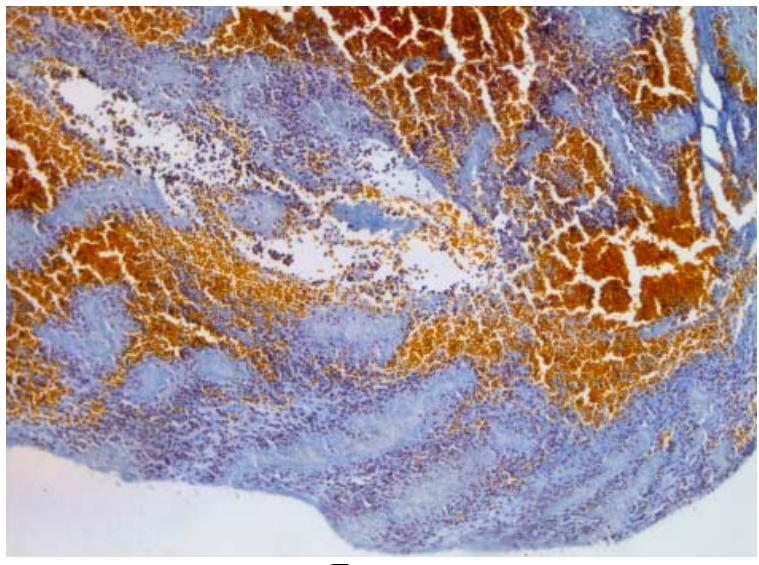

Б

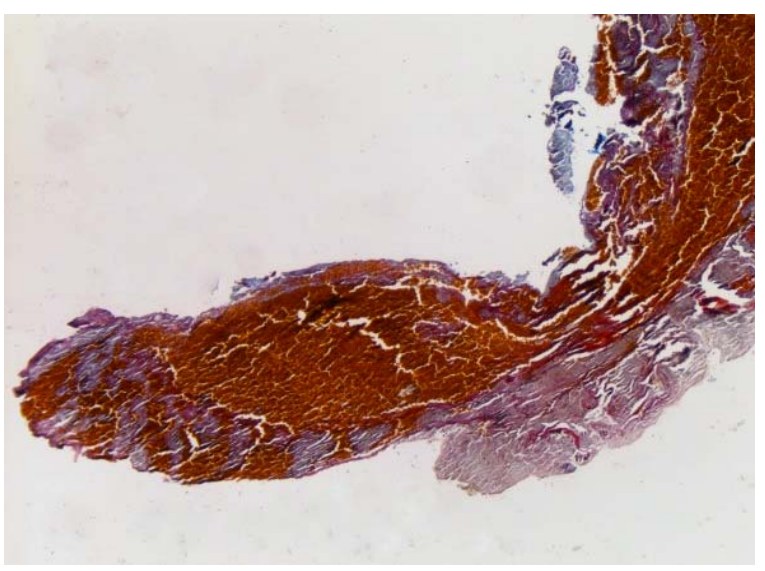

B

View of thrombi macroscopically and microscopically.

A) Macroscopic image of the thrombus obtained by thromboaspiration;

B) Staining of the thrombus by the method of Zerbino-Lukasevich. The thrombus is old, with a layered structure and peripheral infiltration with neutrophils;

C) Staining of the thrombus by the method of Zerbino-Lukasevich.

Thrombus is fresh, without a layered structure and peripheral infiltration with neutrophils

\section{RESULTS AND DISCUSSION}

Characteristics of the morphological structure of intracoronary thrombi are presented in Table 2. Samples obtained from $48.45 \%$ of patients met the criteria of the old thrombus, others were fresh. The layered structure of the intracoronary thrombus was established in $60.82 \%$ of patients. Microchannels were detected in a little more than a third of the thrombi obtained (39.18\%). Peripheral infiltration with neutrophilic leukocytes, the so-called "leukocyte bank", was seen in more than half of the obtained samples $(54.64 \%)$. The thrombi obtained by aspiration also differed in macroscopic cha- 
racteristics. Red thrombi were the most common $49.48 \%$, slightly less common - mixed ones - in
$43.30 \%$, and white thrombi were found in only $7.22 \%$ of patients.

Table 1

Initial characteristics of patients

\begin{tabular}{l|ll}
\hline \multicolumn{1}{|c|}{ Characteristic } & Absolute values & $\%$ \\
\hline Male & 80 & 82.47 \\
Diabetes & 21 & 21.65 \\
Hypertension & 56 & 57.73 \\
Adiposity & 40 & 41.24 \\
Dyslipidemia & 32 & 32.99 \\
Chronic kidney disease & 20 & 20.62 \\
Smoking & 55 & 56.70 \\
Professional contact with xenobiotics & 50 & 51.55 \\
Cardiogenic shock & 11 & 11.34 \\
Two- or three-vessel lesion & 39 & 40.21 \\
TIMI 0 before PCCI & 80 & 82.47 \\
MBG 0 before PCCI & & 88.66 \\
Infarct-dependent anterior interventricular branch of the left coronary artery & & 42.27 \\
\hline
\end{tabular}

Analysis of the results of electrocardiographic studies showed the development of pathological QS wave in $45(46.39 \pm 5.06 \%)$ patients. In the correlation analysis, only presence of peripheral infiltration of neutrophils had a significant negative relationship with this indicator $(\mathrm{r}=-0.36 ; \mathrm{p}<0.001)$. In the same direction, but unreliable, relationship with the development of the pathological QS wave was in the old thrombi $(\mathrm{r}=-0.03 ; \mathrm{p}=0.75)$, macroscopically white $(\mathrm{r}=-0.02 ; \mathrm{p}=0.85)$ and mixed $(\mathrm{r}=-0.06 ; \mathrm{p}=0.55)$. There was a tendency to a positive correlation with the above indicator and thrombi, which had microchannels in their thickness, but it did not exceed the limits of statistical significance $(r=0.19 ; p=0.07)$. A positive correlation was also found between the development of the pathological QS wave and the presence of a layered structure of the intracoronary thrombus $(\mathrm{r}=0.11$; $\mathrm{p}=0.28)$, its red color $(\mathrm{r}=0.07 ; \mathrm{p}=0.49)$. $)$, but in both cases the values were unreliable (Table 3 ).

\section{Morphological features of the structure of intracoronary thrombi}

\begin{tabular}{l|cc}
\hline \multicolumn{1}{c|}{ Signs } & Absolute values & $\%$ \\
\hline Old blood clots & 47 & 48.45 \\
Thrombi with a layered structure & 59 & 60.82 \\
Blood clots with microchannels & 38 & 39.18 \\
Thrombi with peripheral infiltration with neutrophilic leukocytes & 53 & 54.64 \\
White blood clots & 7 & 7.22 \\
Red blood clots & 48 & 49.48 \\
Mixed blood clots & 42 & 43.30 \\
\hline
\end{tabular}


The ejection fraction of the left ventricle during echocardiography before the discharge from the hospital was $48.34 \pm 9.39 \%$. The study of correlations of this indicator with different characteristics of intracoronary thrombi obtained during manual thrombo-aspiration made it possible to establish a reliable positive relationship with the presence of infiltration of neutrophilic granulocytes of peripheral areas of the thrombus $(r=0.37 ; \mathrm{p}<0.001)$. The correlation of this indicator with the presence of microchannels in the obtained thrombus samples was significantly negative $(r=-0.26789 ; \mathrm{p}<0.01)$. The correlation between the left ventricular ejection fraction at the time of discharge from the hospital and the presence of an old thrombus $(\mathrm{r}=0.09$; $\mathrm{p}=0.40$ ) was unreliable. The correlation with two macroscopic signs of thrombi was also insignificantly positive: red $(\mathrm{r}=0.01 ; \mathrm{p}=0.93)$ and mixed $(\mathrm{r}=0.02 ; \mathrm{p}=0.85)$. The correlation with white thrombi turned out to be opposite $(\mathrm{r}=-0.06 ; \mathrm{p}=0.58)$. Negative correlation of left ventricular ejection fraction indicators was established with the presence of layered arrangement of fibrin and formed blood elements $(r=-0.06 ; p=0.59)$, but the results were not statistically significant (Table 3 ).

Table 3

\section{Correlation between morphological features of intracoronary thrombi and indicators of structural and functional state of the left ventricle}

\begin{tabular}{|c|c|c|c|c|c|c|c|c|c|c|}
\hline \multirow{2}{*}{$\begin{array}{l}\text { Signs of } \\
\text { blood clots }\end{array}$} & \multicolumn{2}{|c|}{ Pathological QS } & \multicolumn{2}{|c|}{ Ejection fraction } & \multicolumn{2}{|c|}{ Contractility index } & \multicolumn{2}{|c|}{ Dilatation } & \multicolumn{2}{|c|}{$\begin{array}{l}\text { Aneurysm } \\
\text { formation }\end{array}$} \\
\hline & $\mathbf{r}$ & $\mathbf{p}$ & $\mathbf{r}$ & $\mathbf{p}$ & $\mathbf{r}$ & $\mathbf{p}$ & $\mathbf{r}$ & $\mathbf{p}$ & $\mathbf{r}$ & $\mathbf{p}$ \\
\hline Old & -0.03 & 0.75 & 0.09 & 0.40 & -0.15 & 0.14 & 0.01 & 0.97 & -0.04 & 0.68 \\
\hline With a layered structure & 0.11 & 0.28 & -0.06 & 0.59 & 0.11 & 0.27 & 0.10 & 0.32 & -0.04 & 0.69 \\
\hline With microchannels & 0.19 & 0.07 & -0.27 & $<0.01$ & 0.26 & 0.01 & 0.13 & 0.20 & 0.16 & 0.13 \\
\hline $\begin{array}{l}\text { With peripheral } \\
\text { infiltration with } \\
\text { neutrophilic leukocytes }\end{array}$ & -0.36 & $<0.001$ & 0.37 & $<0.001$ & -0.37 & $\mathbf{p}<0.001$ & -0.14 & 0.18 & -0.32 & $\mathbf{p}<\mathbf{0 . 0 1}$ \\
\hline White thrombi & -0.02 & 0.85 & -0.06 & 0.58 & 0.11 & 0.31 & 0.06 & 0.54 & -0.02 & 0.87 \\
\hline Red thrombi & 0.07 & 0.49 & 0.01 & 0.93 & 0.03 & 0.78 & 0.04 & 0.69 & 0.12 & 0.26 \\
\hline Mixed thrombi & -0.06 & 0.55 & 0.02 & 0.85 & -0.08 & 0.41 & -0.08 & 0.46 & -0.11 & 0.29 \\
\hline
\end{tabular}

The total contractility of the left ventricular myocardium at the time of the discharge from the hospital was $1.38[1.25 ; 1.63]$ points. Due to the fact that in this indicator the higher numerical value reflects the worst functional state of the myocardium, the results of the correlation analysis of this indicator are concordant with the results of the analysis of the left ventricular ejection fraction. Significantly negative relationship with the contractility index was the presence of infiltration with neutrophilic granulocytes of peripheral thrombus area $(\mathrm{r}=-0.37 ; \mathrm{p}<0.001)$, and significantly positive the presence of microchannels in the obtained samples of thrombi $(r=0.26 ; p=0.01)$. At the same time, a negative correlation of the above indicator with old $(\mathrm{r}=-0.15 ; \mathrm{p}=0.14)$ and visually mixed thrombi $(\mathrm{r}=-0.08 ; \mathrm{p}=0.41)$ was revealed. The cor- relation with two macroscopic signs of thrombi was unreliable positive: red $(\mathrm{r}=0.03 ; \mathrm{p}=0.78)$ and white $(\mathrm{r}=0.11 ; \mathrm{p}=0.31)$. A similar result was obtained by comparing the index of left ventricular contractility and the layered arrangement of fibrin and thrombi $(\mathrm{r}=0.11 ; \mathrm{p}=0.27)$ (Table 3$)$.

The next indicator under analysis was left ventricular dilatation. It was detected in $44(45.36 \pm 5.05 \%)$ patients. According to the results of correlation analysis, none of our proposed characteristics of thrombi was significantly associated with this indicator. Negative correlation values were obtained for old thrombi (-r=0.01; $\mathrm{p}=0.97)$, thrombi with peripheral infiltration with neutrophilic leukocytes $(\mathrm{r}=-0.14 ; \mathrm{p}=0.18)$ and macroscopically mixed $(\mathrm{r}=$ $0.08 ; \mathrm{p}=0.46)$ ones. Layered structure of arrangement of formed elements and fibrin $(r=0.10$; 
$\mathrm{p}=0.32)$, the presence of microchannels $(\mathrm{r}=0.13$; $\mathrm{p}=0.20)$ and macroscopic features of white $(\mathrm{r}=0.06$; $\mathrm{p}=0.54)$ and red thrombi $(\mathrm{r}=0.04 ; \mathrm{p}=0.69)$ were insignificantly positively correlated with the detection of left ventricular dilatation during echocardiography (Table 3 ).

The last echocardiographic indicator analyzed in our study were the signs of left ventricular aneurysm formation before discharge from the hospital. This pathology was verified in $15(15.46 \pm 3.67 \%)$ patients. A significant negative correlation was found between aneurysm formation and the presence of peripheral thrombus infiltration with neutrophilic leukocytes $(r=-0.32 ; p<0.01)$. Analysis of other correlations did not show statistically significant results. In particular, we obtained weak values of the negative correlation of the signs of left ventricular aneurysm with the following indicators: old thrombi $(\mathrm{r}=-0.04 ; \mathrm{p}=0.68)$, thrombi with a layered structure of arrangement of formed elements and fibrin $(\mathrm{r}=$ $0.04 ; \mathrm{p}=0.69)$, macroscopically white $(\mathrm{r}=-0.02$; $\mathrm{p}=0.87)$ and mixed $(\mathrm{r}=-0.11 ; \mathrm{p}=0.29)$ thrombi. The presence of microchannels $(\mathrm{r}=0.16 ; \mathrm{p}=0.13)$ and red thrombus staining $(\mathrm{r}=0.12 ; \mathrm{p}=0.26)$ had the opposite relationship (Table 3 ).

Based on the results obtained, it can be stated that peripheral infiltration with neutrophilic leukocytes was the main predictor of a positive prognosis in our study. At the same time, there are data from the study of Szarfer J.L. and co-authors (2017) which showed that higher neutrophil count is associated with a lower probability of simple reperfusion, which is a sign of thrombus looseness. However, in this study, attention was paid only to the number of leukocytes without taking into account their arrangement [11]. According to current data, neutrophils play a key role in the formation of thrombi in the coronary artery. They have been shown to create extracellular traps that are the framework for fibrin. At the same time, traps can also create other types of leukocytes, but neutrophilic traps are involved in the early process of thrombogenesis, and traps formed by macrophages play an important role in the processes of thrombus organization [6]. In particular, a study conducted by Mangold A. and coauthors (2019) analyzed thrombi obtained from 111 patients with STEMI, and found that the number of neutrophilic extracellular traps in them is significantly positively correlated with the size of necrosis areas and negatively with the resolution of the ST segment [5].

In all the studies we found, the effect of thrombus age on the prognosis of patients was most often studied, but the age of thrombi was determined by indirect indicators. Fresh were considered thrombi (formed up to 1 day) which had a layered structure of fibrin and intact blood cells. In turn, the old (more than 1 day) - thrombi with homogenization of structural elements or colic necrosis and karyorrhexis of granulocytes, or the germination of smooth muscle cells with/without deposits of fresh connective tissue, or the germination of microchannels in the thrombus. Most of such studies were conducted by Li X. and co-authors (2016). The study included 870 patients with STEMI in whom the morphology of blood clots was studied. In a multivariate analysis, it was found that old blood clots are significantly associated with higher mortality (relative risk 1.9; 95\% confidence interval 1.08-3.32; $\mathrm{p}=0.03$ ) [9]. It has been proven that the presence of old blood clots often accompanies a higher risk of distal embolism during primary percutaneous coronary intervention [10]. In our study, the age of the thrombus was determined by the age of fibrin, which, in our opinion, is a more accurate indicator as some signs of fresh blood clots are present in the presence of old fibrin. That is why we evaluated each morphological feature of the thrombus separately. The presence of a layered structure of arrangement of formed elements and fibrin which is associated with fresh thrombi, in our study did not significantly affect the prognosis. However, the presence of microchannels which is an indisputable sign of the age of the process negatively correlated with the functional state of the myocardium.

It should be noted that our results coincide with the data of other studies, which show that in patients with clinical signs of STEMI up to 12 hours, a thrombi often begins to form a day or more before hospitalization $[9,10]$. Moreover, previous studies have not found an association between the time from onset of symptoms to the balloon (time pain-balloon) and the age of the thrombi [8].

The macroscopic characteristics of the aspiration material, according to the results of our study, did not have a reliable relationship with the structural and functional characteristics of the myocardium at the time of discharge from the hospital. The influence of such features of the structure of the intracoronary thrombus on the prognosis of patients with STEMI was studied by Yang Y. et al. (2016). They showed that the risk of distal embolization was insignificantly higher in patients with red thrombi $(10.9 \%$ vs. $0 \%$; $=0.091)$. The incidence of major cardiovascular events at hospitalization was also significantly higher in this group of patients $(15.6 \%$ vs. $0 \% ; p=0.041)$. However, the stratification of the aspiration material was somewhat different from that used in our study. Mixed thrombi were distributed between the group of white and red 
ones by the predominant color which could affect the final result [12].

\section{CONCLUSION}

The presence of peripheral infiltration of neutrophilic leukocytes in intracoronary thrombi obtained by manual thrombo-aspiration in patients with STEMI is associated with better indicators of left ventricular systolic function (ejection fraction $\mathrm{r}=0.37$, $\mathrm{p}<-0.001$; contractility index $\mathrm{r}=-0.37, \mathrm{p}<0.001)$ and less likely to form an aneurysm $(\mathrm{r}=-0.32, \mathrm{p}<0.001)$ and a QS wave on the ECG $(r=-0.36, p<0.001)$ after $2-3$ months from the onset of the disease. At the same time, the formation of microchannels in the thrombus is associated with poorer recovery of systolic heart function (ejection fraction $\mathrm{r}=-0.27, \mathrm{p}<0.01$; contractility index $\mathrm{r}=-0.26, \mathrm{p}=0.01$ ). It has been established that even in patients with a clinical STEMI duration of less than 12 hours, thrombi older than 1 day are often found in the infarct-dependent area.

Conflict of interest. The authors declare no conflict of interest.

\section{REFERENCES}

1. Lutay MI, Parkhomenko OM, Lysenko GF, et al. [Patient with stable ischemic heart disease in Ukraine and Europe: The CLARIFY registry 5-year results]. Ukrainian cardiology journal. 2018;4:19-30. Ukrainian. doi: http://doi.org/10.31928/1608-635X-2018.4.1930

2. Gurianov VG, Liakh YuYe, Parii VD, Korotkyi OV, Chalyi OV. [Manual on biostatistics. Analysis of the results of medical research in the package EZR (Rstatistics): for masters, interns, clinical residents and graduate students in the field of knowledge "Health"]. Kyiv: Vistka, 2018:206. ISBN 978-617-7157-67-9. Ukrainian.

3. Sokolov MYu. [Register of percutaneous coronary interventions: expanded comparative analysis of results of 2016 and 2017. From reperfusion paradox to decrease of mortality]. Heart and vessels. 2018;3:9-27. Russian. doi: https://doi.org/10.30978/HV2018-3-9

4. Shiller NB, Osipov MO. [Clinical Echocardiography. Second edition]. Moskva: MEDpress; 2018. P. 344. Russian.

5. Mangold A, Alias S, Scherz T, et al. Coronary neutrophil extracellular trap burden and deoxyribonuclease activity in ST-elevation acute coronary syndrome are predictors of ST-segment resolution and infarct size. Circulation Research. 2015;116(7):1182-92. doi: https://doi.org/10.1161/CIRCRESAHA.116.304944

6. Pertiwi K, de Boer O, Mackaaij C, et al. Extracellular traps derived from macrophages, mast cells, eosinophils and neutrophils are generated in a time-dependent manner during atherothrombosis. The Journal of Pathology. 2019;247(4);505-12.

doi: https://doi.org/10.1002/path.5212

7. Thygesen K, Alpert JS, Jaffe AS, et al. Fourth universal definition of myocardial infarction. European Heart Journal. 2019;40(3):237-69. doi: https://doi.org/10.1093/eurheartj/ehy462.
8. Fuijkschot W, Groothuizen W, Appelman Y, et al. Inflammatory cell content of coronary thrombi is dependent on thrombus age in patients with ST-elevation myocardial infarction. Journal of Cardiology. 2017;69(1):394-400. doi: https://doi.org/10.1016/j.jjcc.2016.10.003

9. Li X, Kramer M, Damman P, et al. Older coronary thrombus is an independent predictor of 1-year mortality in acute myocardial infarction. European Journal of Clinical Investigation. 2016;46(6):501-10. doi: https://doi.org/10.1111/eci.12619

10. Nishihira K, Shibata Y, Yamashita A, et al. Relationship between thrombus age in aspirated coronary material and mid-term major adverse cardiac and cerebrovascular events in patients with acute myocardial infarction. Atherosclerosis. 2018;268:138-44. doi: https://doi.org/10.1016/j.atherosclerosis.2017.12.001

11. Szarfer JL, García-Escudero A, Blanco F, et al. Simple mechanical reperfusion in acute myocardial infarction: determinants, prognostic implications and relation with thrombus histology. Medicina (Buenos Aires). 2017;77(5)358-64.

http://www.medicinabuenosaires.com/PMID/29044010.pdf

12. Yang Y, Li J, Xu W, et al. Thrombus aspirated from patients with ST-elevation myocardial infarction: Clinical and angiographic outcomes. Journal of Internal Medicine Research. 2016;44(6):1514-23. doi: https://doi.org/10.1177/0300060516667373

13. Ibanez B, James S, Agewall S, et al. 2017 ESC Guidelines for the management of acute myocardial infarction in patients presenting with ST-segment elevation: The Task Force for the management of acute myocardial infarction in patients presenting with STsegment elevation of the European Society of Cardiology (ESC). European Heart Journal. 2018;39(2):119-77. doi: https://doi.org/10.1093/eurheartj/ehx393

\section{СПИСОК ЛІТЕРАТУРИ}

1. Пацієнт зі стабільною ішемічною хворобою серця в Україні та Європі: результати 5-річного

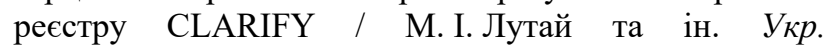
кардіологічний журнал. 2018. № 4. С. 19-30. DOI: http://doi.org/10.31928/1608-635X-2018.4.1930
2. Посібник з біостатистики. Аналіз результатів медичних досліджень у пакеті EZR (R-statistics): для магістрів, інтернів, клінічних ординаторів та аспірантів галузі знань "Охорона здоров'я" / В. Г. Гур'янов, та ін. Київ: Вістка, 2018. 206 с. ISBN 978-617-7157-67-9. 
3. Соколов М. Ю. Реєстр перкутанных коронарних втручань: розширений порівняльний аналіз результатів 2016 і 2017 року. Від реперфузійного парадоксу до зниження летальності. Серцее $i$ судини. 2018. № 3. C. 9-27.

DOI: https://doi.org/10.30978/HV2018-3-9

4. Шиллер Н. Б., Осипов М. О. Клиническая эхокардиография. 2-е изд. Москва: МЕДпресс, 2018. 344 с.

5. Coronary neutrophil extracellular trap burden and deoxyribonuclease activity in ST-elevation acute coronary syndrome are predictors of ST-segment resolution and infarct size / A. Mangold et al. Circulation Research. 2015. Vol. 116, No. 7. P. 1182-1192. DOI: https://doi.org/10.1161/CIRCRESAHA.116.304944

6. Extracellular traps derived from macrophages, mast cells, eosinophils and neutrophils are generated in a time-dependent manner during atherothrombosis / K. R. Pertiwi et al. The Journal of Pathology. 2019. Vol. 247, No. 4. P. 505-512.

DOI: https://doi.org/10.1002/path.5212

7. Fourth universal definition of myocardial infarction / K. Thygesen et al. European Heart Journal. 2019. Vol. 40, No. 3. P. 237-269.

DOI: https://doi.org/10.1093/eurheartj/ehy462.

8. Inflammatory cell content of coronary thrombi is dependent on thrombus age in patients with ST-elevation myocardial infarction / W. W. Fuijkschot et al. Journal of Cardiology. 2017. Vol. 69, No. 1. P. 394-400. DOI: https://doi.org/10.1016/j.jjcc.2016.10.003
9. Older coronary thrombus is an independent predictor of 1-year mortality in acute myocardial infarction / LiX et al. European Journal of Clinical Investigation. 2016. Vol.46, No.6. P. 501-510. DOI: https://doi.org/10.1111/eci.12619

10. Relationship between thrombus age in aspirated coronary material and mid-term major adverse cardiac and cerebrovascular events in patients with acute myocardial infarction / K. Nishihira et al. Atherosclerosis. 2018. No. 268. P. 138-144.

DOI: https://doi.org/10.1016/j.atherosclerosis.2017.12.001

11. Simple mechanical reperfusion in acute myocardial infarction: determinants, prognostic implications and relation with thrombus histology / J. L. Szarfer et al. Medicina (Buenos Aires). 2017. Vol. 77, No. 5. P. 358-364. URL: www.medicinabuenosaires.com/PMID/29044010.pdf

12. Thrombus aspirated from patients with STelevation myocardial infarction: Clinical and angiographic outcomes / Y. Yang et al. Journal of Internal Medicine Research. 2016. Vol. 44. No. 6. P. 1514-1523. DOI: https://doi.org/10.1177/0300060516667373

13. 2017 ESC Guidelines for the management of acute myocardial infarction in patients presenting with ST-segment elevation: The Task Force for the management of acute myocardial infarction in patients presenting with ST-segment elevation of the European Society of Cardiology (ESC) / B. Ibanez et al. Eur. Heart Journal. 2018. Vol. 39, No. 2. P. 119-177. DOI: https://doi.org/10.1093/eurheartj/ehx393

The article was received 2020.04.07 